\title{
Synthesis and conductivity of proton-electrolyte membranes based on hybrid inorganic-organic copolymers
}

\author{
Siwen Li, Meilin Liu* \\ School of Material Science and Engineering, Georgia Institute of Technology, 771 Ferst Drive, Atlanta, GA 30332, USA
}

Received 30 April 2003; received in revised form 6 July 2003; accepted 2 August 2003

\begin{abstract}
A class of new proton-electrolyte membranes (PEM) based on inorganic-organic copolymers were synthesized from 3-glycidoxypropyltrimethoxysilane (GPTS), sulfonated phenyltriethoxysilane (SPS), tetraethoxysilane (TEOS) and $\mathrm{H}_{3} \mathrm{PO}_{4}$. Their thermal stability, microstructure, and proton conductivity were investigated under the conditions for PEM fuel cell operation. TGA-DSC analysis indicated that these membranes are thermally stable up to $180^{\circ} \mathrm{C}$. Scanning electron microscope (SEM) micrographs show that the membranes are dense. A proton conductivity of $1.6 \times 10^{-3} \mathrm{~S} / \mathrm{cm}$ was observed at $100^{\circ} \mathrm{C}$ in a dry atmosphere for a sample with 0.5 mol GPTS and $1 \mathrm{~mol} \mathrm{H}_{3} \mathrm{PO}_{4}$ in $1 \mathrm{~mol} \mathrm{Si}$, representing the highest proton conductivity in anhydrous state among PEMs ever reported. In an environment with $15 \%$ relative humidity (RH), the proton conductivity increased to $3.6 \times 10^{-2} \mathrm{~S} / \mathrm{cm}$ at $120^{\circ} \mathrm{C}$. The proton conductivity increases with $\mathrm{H}_{3} \mathrm{PO}_{4}$ contents and relative humidity. The hybrid inorganic-organic materials can be readily fabricated in membrane form with thickness as thin as $20 \mu \mathrm{m}$ on porous electrodes; they have great potential to be used as the electrolytes for high-temperature PEM fuel cells.
\end{abstract}

(c) 2003 Elsevier Ltd. All rights reserved.

Keywords: Proton conductivity; Fuel cell; Phosphorous acid; Hybrid; Direct methanol fuel cell

\section{Introduction}

The use of solid electrolyte membranes of high proton conductivity $(>0.01 \mathrm{~S} / \mathrm{cm})$ in medium temperature range $\left(100-200{ }^{\circ} \mathrm{C}\right)$ with little or no dependence on humidity could greatly improve the energy efficiency of fuel cells, minimize CO-poisoning of Pt catalyst, and reduce the size (weight and volume) of the humidifier [1,2]. Such membranes are also a critical component in hydrogen separation/purification, contaminant removal, gas sensing, and other processes relevant to energy storage and conversion. However, the existing proton-electrolyte membranes (PEMs) display adequate proton conductivity only when saturated with water vapor, limiting the operation temperature of the fuel cells to about $80^{\circ} \mathrm{C}$ [3-6]. Further, the existing membranes such as Nafion suffer other serious disadvantages, including methanol crossover, high cost, and poor hydrophilicity [7-9]. These limitations have stimulated the development of other proton conducting membranes. Nanometer-sized hygroscopic

\footnotetext{
* Corresponding author. Tel.: +1-404-894-6114; fax: +1-404-894-9140

E-mail address: meilin.liu@mse.gatech.edu (M. Liu).
}

metal oxides have been incorporated into polymer proton electrolytes; however, the improvement in properties has been very limited $[2,10]$. Polybenzimidazole (PBI) doped with $300-600 \%$ mol of $\mathrm{H}_{3} \mathrm{PO}_{4}\left(3-6 \mathrm{H}_{3} \mathrm{PO}_{4}\right.$ molecules per PBI repeat unit) has been reported to have proton conductivity of greater than $10^{-2} \mathrm{~S} / \mathrm{cm}$ above $150^{\circ} \mathrm{C}$ [11]. In anhydrous state, however, the proton conductivity is low, inadequate for fuel cell applications [12,13]. In addition, $\mathrm{H}_{3} \mathrm{PO}_{4}$ can easily leach out from the membranes, especially when $\mathrm{H}_{3} \mathrm{PO}_{4}$ content is high. Other $\mathrm{H}_{3} \mathrm{PO}_{4}$-containing polymer membranes have poor mechanical and chemical stability or low proton conductivity compared with $\mathrm{PBI}-\mathrm{H}_{3} \mathrm{PO}_{4}$ system [13]. Hybrid inorganic-organic proton conducting membranes doped with proton-conductive inorganic compounds, such as $\mathrm{Zr}\left(\mathrm{HPO}_{4}\right)_{2} \cdot \mathrm{H}_{2} \mathrm{O}$ and silicotungstic acid $\left(\mathrm{SiO}_{2} \cdot 12 \mathrm{WO}_{3} \cdot 26 \mathrm{H}_{2} \mathrm{O}\right)$, or functional groups (mainly $-\mathrm{SO}_{3} \mathrm{H},-\mathrm{PO}_{3} \mathrm{H}_{2}$ ), have very low proton conductivity in anhydrous state [13-15]. It was reported that phosphosilicate gel prepared from $\mathrm{H}_{3} \mathrm{PO}_{4}$ and tetraethoxysilane (TEOS) has high proton conductivity $\left(10^{-3}\right.$ to $10^{-2} \mathrm{~S} / \mathrm{cm}$ depending on the water content in the gel) above $100^{\circ} \mathrm{C}$ in low humidity (relative humidity, RH 1-2\%) [14,16]. However, such gels are too brittle and have little mechanical flexibility to 
be practically useful. Styrene-ethylene-butylene-styrene (SEBS) and other polymers were added to P/Si gel powders to form composite membranes by pressing [15]. But the improvement in mechanical properties was limited and the proton conductivity was reduced because SEBS is non-proton conductive. Another fatal problem is that the isolated $\mathrm{H}_{3} \mathrm{PO}_{4}$ in the gel reacts with $\mathrm{Si}-\mathrm{O}$ oxide of the gel, leading to a decrease in proton conductivity with time above $100^{\circ} \mathrm{C}$. Accordingly, the development of novel electrolyte membranes with high density, good mechanical strength, and high proton conductivity in low humidity is still the key to the successful development of high-temperature PEM fuel cells, direct methanol fuel cells (DMFCs), and other electrochemical devices.

Schematically shown in Fig. 1(a) is the molecule structure of GPTS, which is frequently used in the preparation of dense hybrid copolymers for hard coatings, contact lens, and optical parts, because the formed hybrid copolymers have excellent mechanical properties [17,18]. In the presence of $\mathrm{H}^{+}$and $\mathrm{H}_{2} \mathrm{O}$, the epoxide ring will open to form $-\mathrm{OH}$ groups by the hydrolysis reaction [15]. The organic chains can be connected with each other through $-\mathrm{C}-\mathrm{O}-\mathrm{C}$ bonds by condensation in a heating process to form polyethylene oxide (PEO) chains. It is expected that the silicate gels from TEOS and GPTS will form -Si-O-Si- backbones connected by PEO chains through sol-gel process, as schematically shown in Fig. 1(b). The hybrid copolymers should have the advantages of both the silicon gel and the hybrid copolymers, including the ability to absorb $\mathrm{H}_{3} \mathrm{PO}_{4}$, good affinity to water, excellent mechanical properties, and dense structure. In this paper, a series of such hybrid inorganic-organic membranes doped with $\mathrm{H}_{3} \mathrm{PO}_{4}$ were prepared from GPTS, sulfonated phenyltriethoxysilane (SPS), and TEOS. The pro-

(a)
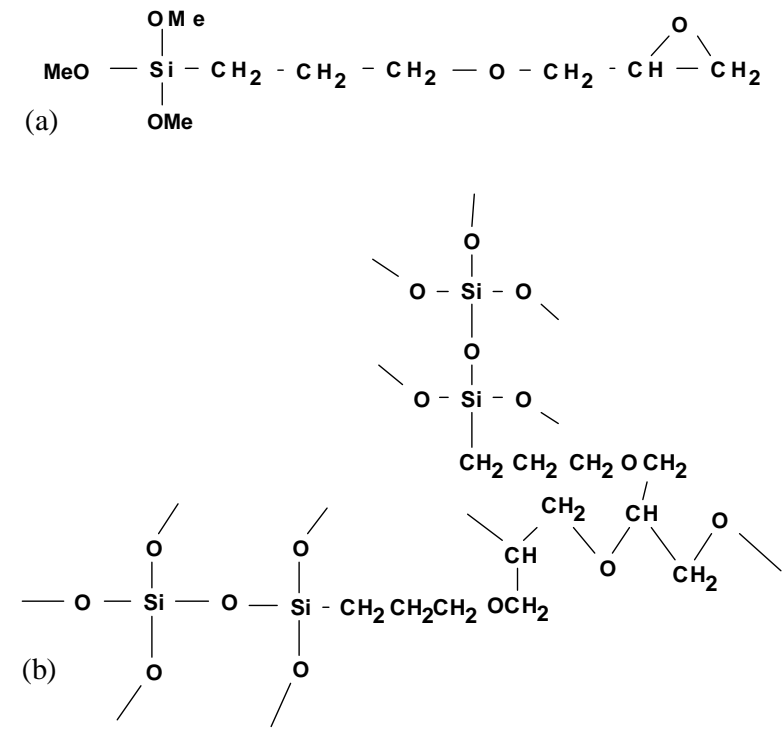

Fig. 1. (a) The schematic molecular structure of a 3-glycidoxypropyltrimethoxysilanne (GPTS) molecule and (b) the ideal structure of a new hybrid inorganic-organic copolymer. ton conductivity is about $10^{-3} \mathrm{~S} / \mathrm{cm}$ above $100^{\circ} \mathrm{C}$ in a dry atmosphere, and reaches $10^{-2} \mathrm{~S} / \mathrm{cm}$ in an atmosphere with $\mathrm{RH}$ of about $20 \%$. In addition, a process for fabrication of such membranes as thin as $20 \mu \mathrm{m}$ on porous electrodes has also been developed.

\section{Experimental}

\subsection{Preparation of the sols}

SPS was synthesized by reaction of phenyltriethoxysilane (Aldrich, 98\%) and chlorosulfonic acid (Alfa, 99\%) as described elsewhere [10]. The precursor solution was prepared by mixing GPTS (Alfa, 96\%), TEOS (Aldrich, 98\%), and SPS with ethanol. After stirring for $20 \mathrm{~min}, 0.5 \mathrm{~N} \mathrm{HCl}$ aqueous solution was added dropwise to the precursor solution, and stirred for $30 \mathrm{~min}$. After $\mathrm{H}_{3} \mathrm{PO}_{4}$ was added dropwise, the solution was stirred for at least $12 \mathrm{~h}$ to form sols. The amount of water added is four times of the total $\mathrm{Si}$ in moles. The samples were labeled by their mole composition as $(100-x-y)$ SPS $-x$ TEOS $-y$ GPTS $-z \mathrm{H}_{3} \mathrm{PO}_{4}$, where $z$ is the ratio of $\mathrm{H}_{3} \mathrm{PO}_{4}$ to total $\mathrm{Si} ; x$ varied from 100 to $40, y$ from 0 to 50 , and $z$ from 50 to 100 .

\subsection{Preparation of self-standing membranes}

To make self-standing membranes, the sol was cast onto petri dishes. After the petri dish was covered and kept in a dry oven at $60^{\circ} \mathrm{C}$ for 3 days, a small hole was opened on the cover to allow the evaporation of the organic solution and water slowly in about 6 days. Then the covers were removed and the membranes were dried at $60^{\circ} \mathrm{C}$ for another 3 days, at $80^{\circ} \mathrm{C}$ for $12 \mathrm{~h}$, and at $100^{\circ} \mathrm{C}$ for $3 \mathrm{~h}$.

\subsection{Preparation of membranes sandwiched between carbon electrodes}

The hybrid membranes sandwiched between porous carbon boards were prepared as follows: the porous carbon board was held vertically to let the sol dropped on the top to flow down naturally; when the sol reached the bottom of the board, flip the sample vertically and let the sol flow down again. The liquid-film-covered carbon board was left in air for 1 or $2 \mathrm{~h}$ until the film geled. Then two film-covered carbon boards were put together face to face, pressed by a glass slide, and then left in air for 2 days. Subsequently, the sandwich was dried in an oven (with a heating rate of $0.5^{\circ} \mathrm{C} / \mathrm{min}$ ) at $60^{\circ} \mathrm{C}$ for $12 \mathrm{~h}$, at $80^{\circ} \mathrm{C}$ for $6 \mathrm{~h}$, and at $120^{\circ} \mathrm{C}$ for $1 \mathrm{~h}$.

\subsection{Characterization}

$\mathrm{X}$-ray diffraction patterns of the gels were obtained on a Philips PW 1800 diffractometer with $\mathrm{Cu} \mathrm{K} \alpha$ radiation. The morphologies and element composition were characterized 
with a scanning electron microscope (SEM, Hitachi S-800). Thermogravimetric analysis (TGA) and differential scanning calorimetry (DSC) were performed on a Rheometric Scientific STA 1500 in dry air. ${ }^{31}$ P MAS-NMR spectra were acquired using a Bruker DSX 400 spectrometer operating at 161.86 MHz. The ${ }^{31} \mathrm{P}$ signal from $\mathrm{NH}_{4} \mathrm{H}_{2} \mathrm{PO}_{4}$ at $298 \mathrm{~K}$ was referenced to $\delta=0 \mathrm{ppm}$. The small pieces of membranes with about $0.5 \mathrm{~mm}$ thickness and $0.6 \mathrm{~cm}^{2}$ area were used to measure the proton conductivity using a SI 1255 frequency response analyzer and SI 1286 potentiostate/galvanostate in the frequency range of $0.01 \mathrm{~Hz}$ to $5 \mathrm{MHz}$. Two silver pellets were used as the electrodes. The measurements were run in a small dry oven with flowing $\mathrm{N}_{2}$ gas. To measure the proton conductivities of the membranes in anhydrous sate, all membranes were dried in dry $\mathrm{N}_{2}$ gas at $80^{\circ} \mathrm{C}$ for $3 \mathrm{~h}$ and at $100^{\circ} \mathrm{C}$ for $6 \mathrm{~h}$, or at $100^{\circ} \mathrm{C}$ for $1 \mathrm{~h}$ and at $120^{\circ} \mathrm{C}$ for $3 \mathrm{~h}$, to remove water in the membranes before measurements. Saturated $\mathrm{MgCl}_{2}$ aqueous solution in a closed chamber was used to control the $\mathrm{RH}$ at $22.5 \%\left(100^{\circ} \mathrm{C}\right)$ and $15 \%\left(120^{\circ} \mathrm{C}\right)$.

\section{Results and discussion}

\subsection{Appearance of the membranes and films}

All as-prepared self-standing membranes are transparent, and the mechanical flexibility increases with the GPTS contents. The membranes of $15 \mathrm{~cm}^{2}$ with different thickness can be readily prepared by casting on plastic or glass petri dishes. The samples without SPS remained colorless after being kept at $100{ }^{\circ} \mathrm{C}$ for $3 \mathrm{~h}$ when the content of $\mathrm{H}_{3} \mathrm{PO}_{4}$ is less than 80. The samples with 20 SPS-57 TEOS-23 GPTS- $77 \mathrm{H}_{3} \mathrm{PO}_{4}$ turned to brown when kept at $100^{\circ} \mathrm{C}$ for $3 \mathrm{~h}$ in a dry atmosphere. Such color change may be attributed to the fact that the $-\mathrm{SO}_{3} \mathrm{H}$ groups may react with the $-\mathrm{OH}$ groups to form $-\mathrm{S}-\mathrm{O}-\mathrm{C}$ bridges and water at high temperatures [19]. With increasing GPTS contents, the membranes become more difficult to separate from the petri dishes during casting of PEM due to the increasing adhesion of the membranes to glass and plastics [17]. Meanwhile, the shrinkage of the membranes in the drying process decreases with increasing GPTS contents. There is even no observable shrinkage in the sample with 50 GPTS. Such hybrid inorganic-organic copolymer materials are easy to be made into thin membranes supported by porous carbon electrode boards. It is noted that no deliquesce was observed on the surface of the membranes with GPTS content larger than 30 after they were left in ambient air at room temperature for several days, or kept in an environment with RH $20 \%$ above $100^{\circ} \mathrm{C}$ for several hours. The good stability of $\mathrm{H}_{3} \mathrm{PO}_{4}$ in the new membranes should be attributed to the high affinity of $\mathrm{Si}-\mathrm{O}$ based hybrid inorganic-organic network to $\mathrm{H}_{3} \mathrm{PO}_{4}$ molecules $[14,16]$.

\subsection{Microstructure of the membranes}

Shown in Fig. 2 is an SEM picture of the fractured surface of a membrane with composition of 0 SPS-50 TEOS-50

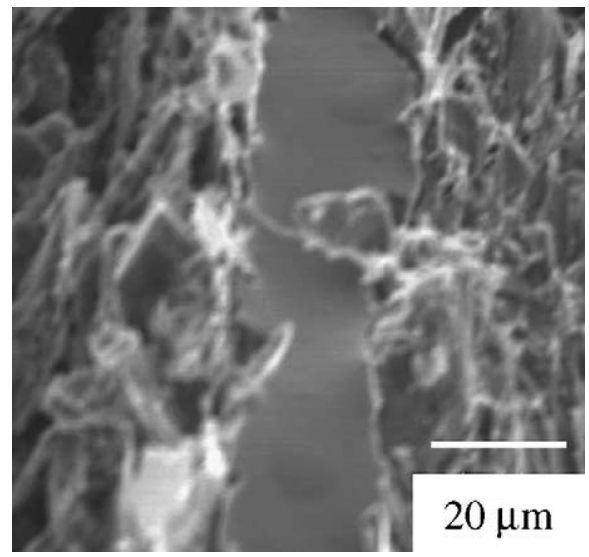

Fig. 2. An SEM micrograph showing the cross-sectional view of a fractured copolymer membrane (with composition of 0 SPS-50 TEOS-50 GPTS-50 P) sandwiched between two porous carbon electrodes.

GPTS-50 $\mathrm{H}_{3} \mathrm{PO}_{4}$, supported by porous carbon electrode boards. It is about $20 \mu \mathrm{m}$ thick and $5 \mathrm{~cm}^{2}$ in area without cracks. Higher magnification SEM views of the fractured surface of two hybrid inorganic-organic membranes indicate that both samples are dense, and the sample with 50 GPTS has a smoother surface than that with 23 GPTS.

\subsection{Status of phosphoric acid in the membranes}

The status of phosphorous acid in the hybrid inorganicorganic membranes was studied using ${ }^{31} \mathrm{P}$ MAS-NMR. Shown in Fig. 3 are the NMR spectra of two samples, 0 SPS-77 TEOS-23 GPTS-77 $\mathrm{H}_{3} \mathrm{PO}_{4}$ and 0 SPS-50 TEOS-50 GPTS-100 $\mathrm{H}_{3} \mathrm{PO}_{4}$. Three ${ }^{31} \mathrm{P}$ resonance peaks were observed; one of which is too weak to be visible in the full spectra. The extremely strong peak at $\delta=-0.5 \mathrm{ppm}$ is attributed to the undissociated $\mathrm{H}_{3} \mathrm{PO}_{4}$ and other dissociated species such as $\mathrm{H}_{4} \mathrm{PO}_{4}{ }^{+}$and $\mathrm{H}_{2} \mathrm{PO}_{4}{ }^{-}[14,20]$. The latter two species are known to be within $2 \mathrm{ppm}$ of the undissociated $\mathrm{H}_{3} \mathrm{PO}_{4}$ signal [20]. The other two weak peaks at $\delta=-11.523 .5 \mathrm{ppm}$ are due to the end and middle units of pyrophosphoric acid and tripolyphosphoric acid $[14,20]$. It

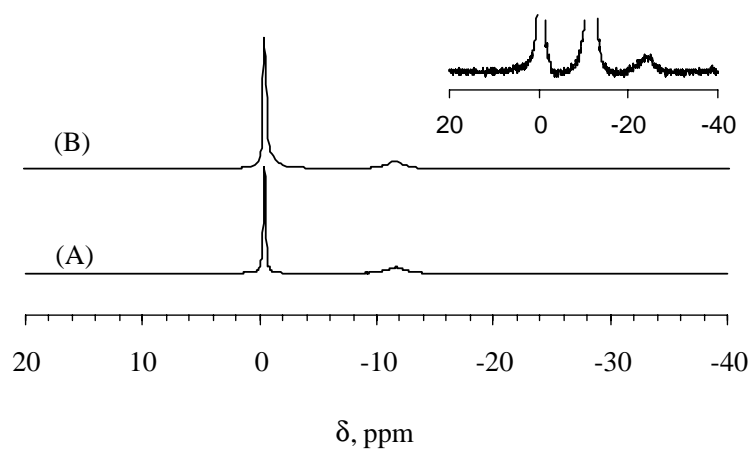

Fig. $3 .{ }^{31} \mathrm{P}$ NMR spectra of two hybrid inorganic-organic membranes with composition of (A) 0 SPS-77 TEOS-23 GPTS-77 $\mathrm{H}_{3} \mathrm{PO}_{4}$ and (B) 0 SPS-50 TEOS-50 GPTS-100 $\mathrm{H}_{3} \mathrm{PO}_{4}$. Inset: spectra of A with magnification of intensity to show the weak peak near $-24 \mathrm{ppm}$. 
should be mentioned that the weak peak at $\delta=-11.5 \mathrm{ppm}$ may be assigned to the phosphates bound to one silicon atom through $\mathrm{P}-\mathrm{O}-\mathrm{Si}$ bonds, which means that part of $\mathrm{H}_{3} \mathrm{PO}_{4}$ was attached to the $\mathrm{Si}-\mathrm{O}-\mathrm{Si}$ network in the hybrid inorganic-organic copolymer $[21,22]$. However, the integral of the two weak peaks is only about $20 \%$ of the total ${ }^{31} \mathrm{P}$ resonance peaks, implying that about $80 \%$ of phosphoric acid exists in the free form, including undissociated $\mathrm{H}_{3} \mathrm{PO}_{4}$ and dissociated species such as $\mathrm{H}_{4} \mathrm{PO}_{4}{ }^{+}$and $\mathrm{H}_{2} \mathrm{PO}_{4}{ }^{-}$.

\subsection{Phase analysis}

The structures of the as-obtained (at $100^{\circ} \mathrm{C}$ for $6 \mathrm{~h}$ ) hybrid inorganic-organic membranes with 50 GPTS and those further dried at $150^{\circ} \mathrm{C}$ for $3 \mathrm{~h}$ were studied by XRD (see Fig. 4). Both as-obtained membranes are amorphous, but with a weak broad peak near $2 \theta=22^{\circ}$, which may be assigned to the partial crystallization of the polymers formed among GPTS [18]. After the membranes were kept at $150^{\circ} \mathrm{C}$ for $3 \mathrm{~h}$, several weak peaks appeared which can be assigned to the $\mathrm{Si}-\mathrm{O}$ oxide (see JCPDS card 03-1092). No peaks of $\mathrm{Si}-\mathrm{P}-\mathrm{O}$ compounds (such as $\mathrm{Si}_{5} \mathrm{P}_{6} \mathrm{O}_{25}$ and $\mathrm{SiP}_{2} \mathrm{O}_{7}$ ) were observable in the spectrum [14,23]. Obviously, no crystallization between $\mathrm{Si}-\mathrm{O}$ and $\mathrm{H}_{3} \mathrm{PO}_{4}$ took place in the heating process below $150{ }^{\circ} \mathrm{C}$ as observed in the $\mathrm{SiO}-\mathrm{H}_{3} \mathrm{PO}_{4}$ gels.

\subsection{Thermal stability}

Shown in Fig. 5 are the TGA-DSC curves of the sample with composition of 9 SPS-50 TEOS-50 GPTS- $50 \mathrm{H}_{3} \mathrm{PO}_{4}$ in dry air from room temperature to $400{ }^{\circ} \mathrm{C}$. There are mainly three mass-loss steps in the TGA curve. The small weight loss from room temperature to $180^{\circ} \mathrm{C}$ corresponds to the evaporation of the water and the small organic molecules in the membrane. The quick weight loss started near $180^{\circ} \mathrm{C}$

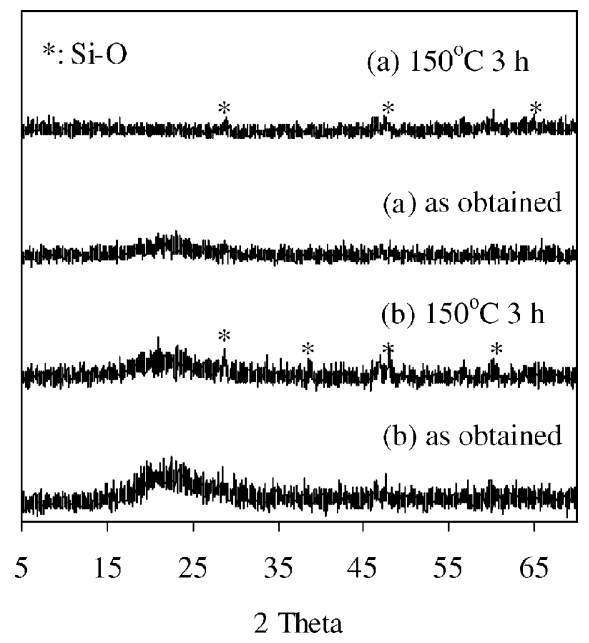

Fig. 4. XRD patterns of hybrid inorganic-organic membranes (a) 0 SPS-50 TEOS-50 GPTS-50 $\mathrm{H}_{3} \mathrm{PO}_{4}$ and (b) 9 SPS-50 TEOS-50 GPTS-50 $\mathrm{H}_{3} \mathrm{PO}_{4}$. The membranes were dried at $100^{\circ} \mathrm{C}$ for $6 \mathrm{~h}$ (as-obtained), and further dried at $150^{\circ} \mathrm{C}$ for $3 \mathrm{~h}$ in air.

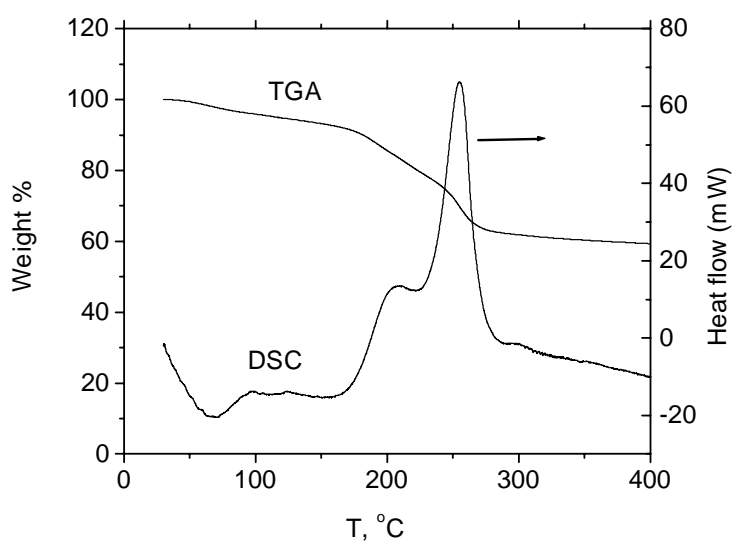

Fig. 5. TGA and DSC curves for a sample with composition of 9 SPS-50 TEOS-50 GPTS-50 $\mathrm{H}_{3} \mathrm{PO}_{4}$ measured in dry air at a heating rate of $5{ }^{\circ} \mathrm{C} / \mathrm{min}$.

may be attributed to the condensation of phosphoric acid doped in the membranes to form polyphosphoric acid and the decomposition of $-\mathrm{SO}_{3} \mathrm{H}$ groups $[14,23,25]$. The decomposition of the organic part of the copolymers starts at $250^{\circ} \mathrm{C}$. Correspondingly, there appears an exothermic peak at $260^{\circ} \mathrm{C}$ in the DSC curve [24,25]. In addition, there is an unknown exothermic peak at $220^{\circ} \mathrm{C}$. The hybrid inorganic-organic membranes are therefore stable up to $180^{\circ} \mathrm{C}$ in dry air.

\subsection{Proton conductivity}

Shown in Fig. 6 are the proton conductivities of anhydrous membranes as measured in dry $\mathrm{N}_{2}$ atmosphere using impedance spectroscopy. In general, proton conductivity increased with $\mathrm{H}_{3} \mathrm{PO}_{4}$ content, reaching $1.6 \times 10^{-3} \mathrm{~S} / \mathrm{cm}$

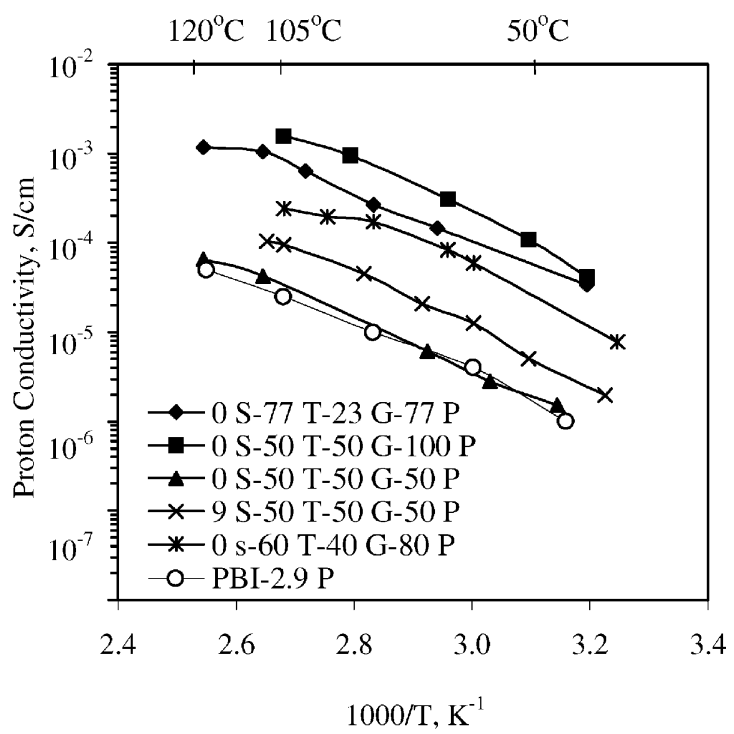

Fig. 6. Proton conductivities of hybrid inorganic-organic membranes with different compositions as measured in a dry atmosphere using impedance spectroscopy (the data of $\mathrm{PBI}-2.9-\mathrm{H}_{3} \mathrm{PO}_{4}$ are from Fig. 29 in ref. [13]). 
Table 1

Proton conductivities $(\mathrm{S} / \mathrm{cm})$ of three new membranes under the conditions with different relative humidity

\begin{tabular}{|c|c|c|c|c|}
\hline \multirow[t]{2}{*}{ Samples } & \multicolumn{2}{|l|}{$100^{\circ} \mathrm{C}$} & \multicolumn{2}{|l|}{$120^{\circ} \mathrm{C}$} \\
\hline & $1.7 \% \mathrm{RH}$ & $22.5 \% \mathrm{RH}$ & $1 \% \mathrm{RH}$ & $15 \% \mathrm{RH}$ \\
\hline 0 SPS-77 TEOS-23 GPTS-50 P & $1.9 \times 10^{-3}$ & - & $3.3 \times 10^{-3}$ & - \\
\hline 9 SPS-50 TEOS-41 GPTS-50 P & $2.7 \times 10^{-4}$ & $0.5 \times 10^{-2}$ & $4.2 \times 10^{-4}$ & $1.0 \times 10^{-2}$ \\
\hline 0 SPS-50 TEOS-50 GPTS-100 P & $1.9 \times 10^{-3}$ & $1.1 \times 10^{-2}$ & $3.7 \times 10^{-3}$ & $3.6 \times 10^{-2}$ \\
\hline
\end{tabular}

at $100^{\circ} \mathrm{C}$ for a sample with composition of 0 SPS-50 TEOS-50 GPTS-100 $\mathrm{H}_{3} \mathrm{PO}_{4}$, which is 40 times higher than that of the sample with composition of 0 SPS-50 TEOS-50 GPTS-50 $\mathrm{H}_{3} \mathrm{PO}_{4}$. These results confirmed that the proton conduction in the hybrid membranes originates primarily from the dissociation among the $\mathrm{H}_{3} \mathrm{PO}_{4}$ molecules doped in the membranes [26]. Comparing the proton conductivity of sample 0 SPS-77 TEOS-23 GPTS-77 $\mathrm{H}_{3} \mathrm{PO}_{4}$ with that of 0 SPS-60 TEOS-40 GPTS- $80 \mathrm{H}_{3} \mathrm{PO}_{4}$, we can find that the proton conductivity decreases with increasing GPTS content. This can be explained by the fact that the $\mathrm{H}_{3} \mathrm{PO}_{4}$ concentration decreases with increasing GPTS contents. It is reported that $\mathrm{PBI}-6-\mathrm{H}_{3} \mathrm{PO}_{4}$ has a proton conductivity of $2 \times 10^{-3} \mathrm{~S} / \mathrm{cm}$ at $100^{\circ} \mathrm{C}$ in anhydrous state [26]. However, PBI with high content of $\mathrm{H}_{3} \mathrm{PO}_{4}$ has a problem of $\mathrm{H}_{3} \mathrm{PO}_{4}$ leaching out. In fact, it has been reported that the upper limit of $\mathrm{H}_{3} \mathrm{PO}_{4}$ content in PBI is $2.9 \mathrm{~mol}$ [13]. The proton conductivity of $\mathrm{PBI}-2.9-\mathrm{H}_{3} \mathrm{PO}_{4}$ under dry conditions at $100^{\circ} \mathrm{C}$ is about $3 \times 10^{-5} \mathrm{~S} / \mathrm{cm}$ [13], as shown in Fig. 6 for comparison. Obviously, our new hybrid inorganic-organic membranes have much higher proton conductivity than PBI- $\mathrm{H}_{3} \mathrm{PO}_{4}$ membranes under similar conditions. The proton conductivity of the sample with composition of 9 SPS-50 TEOS-50 GPTS-50 $\mathrm{H}_{3} \mathrm{PO}_{4}$ with $-\mathrm{SO}_{3} \mathrm{H}$ groups is twice of that of the sample 0 SPS-50 TEOS-50 GPTS-50 $\mathrm{H}_{3} \mathrm{PO}_{4}$. This can be attributed to the fact that the $-\mathrm{SO}_{3} \mathrm{H}$ groups interact with $\mathrm{H}_{3} \mathrm{PO}_{4}$ in the membranes and create more $\mathrm{H}^{+}$defects as follows:

$-\mathrm{SO}_{3} \mathrm{H}+\mathrm{H}_{3} \mathrm{PO}_{4}=-\mathrm{SO}_{3}{ }^{-}+\mathrm{H}_{4} \mathrm{PO}_{4}{ }^{+}$

The addition of $\mathrm{H}_{2} \mathrm{SO}_{4}$ in pure $\mathrm{H}_{3} \mathrm{PO}_{4}$ has been reported to reduce the proton conductivity because it increased the viscosity, and thus decreased the proton mobility [27]. In the new membranes, $\mathrm{H}_{3} \mathrm{PO}_{4}$ was dispersed among the hybrid inorganic-organic copolymer framework as shown in Fig. 1(b), and the viscosity change of the membranes caused by the addition of $-\mathrm{SO}_{3} \mathrm{H}$ groups may be small. However, further investigation on the interaction of $-\mathrm{SO}_{3} \mathrm{H}$ groups with $\mathrm{H}_{3} \mathrm{PO}_{4}$ and the framework of the hybrid inorganic-organic membranes is useful to understand the proton transportation mechanism and to further improve the proton conductivity. It is notable that the $\log \sigma$ versus $T^{-1}$ curves are non-linear, indicating that the proton conduction in these samples does not obey Arrhenius law, but shows the character of the Vogel-Tamman-Fucher (VTF) behavior, indicating that segmental motion plays a role in the proton conductivity. The proton transportation in $\mathrm{H}_{3} \mathrm{PO}_{4}$ system follows Grotthuss mechanism [28]. The curvature of proton conductivity dependence on temperature of the hybrid inorganic-organic membranes may reflect the interaction of $\mathrm{H}_{3} \mathrm{PO}_{4}$ species and the flexible PEO chains formed among GPTS.

To check the humidity dependence of the hybrid inorganic-organic membranes, the proton conductivities of the membranes were measured at 100 and $120^{\circ} \mathrm{C}$ in $\mathrm{N}_{2}$ gas through a water bubbler at $25^{\circ} \mathrm{C}$ and in a closed chamber with saturated $\mathrm{MgCl}_{2}$ aqueous solution. The proton conductivities of several samples are list in Table 1. The calculated relative humidity of $\mathrm{N}_{2}$ through the water bubbler is $1.7 \%$ at $100^{\circ} \mathrm{C}$ and $1.0 \%$ at $120^{\circ} \mathrm{C}$, and those in the closed chamber with saturated $\mathrm{MgCl}_{2}$ aqueous solution is about $22.5 \%$ at $100^{\circ} \mathrm{C}$ and $15 \%$ at $120^{\circ} \mathrm{C}$ [29]. The samples were kept at 100 and $120^{\circ} \mathrm{C}$ for several hours before conductivity measured until the measured values were stable. As expected, the proton conductivity increased dramatically with humidity. For example, the proton conductivity at $120^{\circ} \mathrm{C}$ of sample with composition of 9 SPS-50 TEOS-41 GPTS-50 $\mathrm{H}_{3} \mathrm{PO}_{4}$ increased from $6.6 \times 10^{-5} \mathrm{~S} / \mathrm{cm}$ in dry $\mathrm{N}_{2}$ to $4.2 \times 10^{-4} \mathrm{~S} / \mathrm{cm}$ in RH $1.0 \%$, and to $0.99 \times 10^{-2} \mathrm{~S} / \mathrm{cm}$ in $\mathrm{RH} 15 \%$. The proton conductivity of sample with a composition of 0 SPS-50 TEOS-50 GPTS- $100 \mathrm{H}_{3} \mathrm{PO}_{4}$ at $120^{\circ} \mathrm{C}$ increased from $3.7 \times 10^{-3} \mathrm{~S} / \mathrm{cm}$ in $\mathrm{RH} 1.0 \%$ to $3.6 \times 10^{-2} \mathrm{~S} / \mathrm{cm}$ in $\mathrm{RH} 15 \%$. The increase in proton conductivity in wet atmosphere can be attributed to the fast transport of $\mathrm{H}_{3} \mathrm{O}^{+}$as a vehicle of protons $[28,30]$.

\section{Conclusion}

The hybrid inorganic-organic membranes based on GPTS, TEOS, and $\mathrm{H}_{3} \mathrm{PO}_{4}$ have good mechanical properties, dense structure, and high thermal stability. The proton conductivities are over $10^{-2} \mathrm{~S} / \mathrm{cm}$ under conditions with low relative humidity $(<20 \%)$ above $100^{\circ} \mathrm{C}$, representing the highest proton conductivity under similar conditions among the proton conducting materials ever reported, including $\mathrm{PBI}-\mathrm{H}_{3} \mathrm{PO}_{4}[11,13,25]$. Further, these membranes can be easily made into membranes as thin as $20 \mu \mathrm{m}$ on porous carbon boards, thus having great potential for application in high-temperature PEM fuel cells and in DMFCs. Further improvement of the proton conductivity is possible by incorporating more $-\mathrm{SO}_{3} \mathrm{H}$ groups into the copolymers. However, higher $-\mathrm{SO}_{3} \mathrm{H}$ group contents may reduce the thermal stability of the membranes. 


\section{References}

[1] P.L. Antonucci, A.S. Arico, P. Creti, E. Ramunni, V. Antonucci, Solid State Ionics 125 (1999) 431.

[2] M. Watanabe, H. Uchida, M. Emori, J. Phys. Chem. B 102 (1998) 3129.

[3] L. Depre, M. Ingram, C. Poinsignon, M. Popall, Electrochim. Acta 45 (2000) 1377.

[4] K.D. Kreuer, J. Membr. Sci. 185 (2001) 29.

[5] J.M. Bae, I. Honma, M. Murata, T. Yamamoto, M. Rikukawa, N. Ogata, Solid State Ionics 147 (2002) 189.

[6] N. Chen, L. Hong, Solid State Ionics 146 (2002) 377.

[7] S. Surampudi, S.R. Narayanan, E. Vamos, H. Frank, G. Halpert, A. LaConti, J. Kosek, G.K. Surya Prakash, G.A. Olah, J. Power Sources 47 (1994) 377.

[8] A.J. Appleby, F.R. Foulkes (Eds.), Fuel Cell Handbook, Krieger, Malabar, FL, 1993.

[9] K. Tsuruhara, M. Rikukawa, K. Sanui, N. Ogata, Y. Nagasaki, M. Kato, Electrochim. Acta 45 (2000) 1391.

[10] H. Wang, B.A. Holmberg, L. Huang, Z. Wang, A. Mitra, J.M. Norbeck, Y. Yan, J. Mater. Chem. 12 (2002) 834.

[11] J.S. Wainright, J.-T. Wang, D. Weng, R.F. Savinell, M. Lit, J. Electrochem. Soc. 142 (1995) L121.

[12] A. Schechter, R. Savinell, Solid State Ionics 147 (2002) 181.

[13] M. Rikukawa, K. Sanui, Prog. Polym. Sci 25 (2000) 1463.

[14] A. Matsuda, T. Kanzaki, Y. Yoshinori, M. Tatsuminago, T. Minami, Solid State Ionics 139 (2001) 113.
[15] K. Hirata, A. Matsuda, T. Hirata, M. Tatsumisago, T. Minami, J. Sol-Gel Sci. Technol. 17 (2000) 61.

[16] A. Matsuda, T. Kanzaki, M. Tatsuminago, T. Minami, Solid State Ionics 145 (2001) 161

[17] D. Hoebbel, M. Nacken, H. Schmidt, J. Sol-Gel Sci. Technol. 12 (1998) 169

[18] Y. Park, M. Nagai, Solid State Ionics 145 (2001) 149.

[19] G. Alberti, M. Casciola, R. Palombari, Solid State Ionics 58 (1992) 339.

[20] S.H. Chung, Y. Wang, S.G. Greenbaum, W. Bzducha, G. Zukowska, W. Wieczorek, Electrochim. Acta 46 (2001) 1651.

[21] C. Fernandez-Lorenzo, L. Esquivias, P. Barboux, J. Maquet, F. Taulelle, J. Non-Cryst. Solids 176 (1994) 189.

[22] P. Kohli, G.J. Blanchard, Langmuir 16 (2000) 695.

[23] B.I. Lee, W.D. Samuels, L. Wang, G.J. Exarhos, J. Mater. Res. 11 (1996) 134.

[24] I. Honma, Y. Takeda, J.M. Bae, Solid State Ionics 120 (1999) 255

[25] I. Gautier-Luneau, A. Denoyelle, J.Y. Sanchez, C. Poinsignon, Electrochim. Acta 37 (1992) 1615.

[26] A. Schechter, R. Savinell, Solid State Ionics 147 (2002) 181.

[27] R.A. Munson, M.E. Lazarus, J. Phys. Chem. 71 (1967) 3245

[28] Th. Dippel, K.D. Kreuer, J.C. Lassegues, D. Rodriguez, Solid State Ionics 61 (1993) 41.

[29] D.R. Lide, CRC Handbook of Chemistry and Physics, CRC Press, Boca Raton, 1998, pp. 15-26.

[30] K.D. Kreuer, Chem. Mater. 8 (1996) 610. 